\title{
Combined Effect of Acidification and Phytase Supplementation on Calcium and Phosphorus Digestibility and Body Composition of Rohu (Labeo rohita)
}

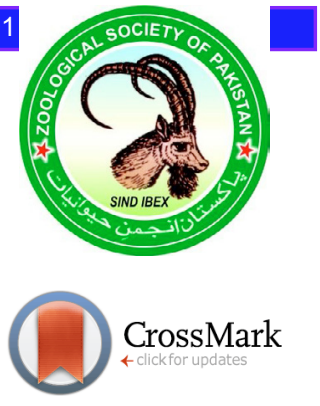

\author{
Naheed Bano* and Muhammad Afzal \\ Department of Zoology, Wild Life and Fisheries, University of Agriculture, \\ Faisalabad, Pakistan
}

\begin{abstract}
A B S T R A C T
Rohu fish is tastiest fish among carps but its production is less than other species due to its slow growth and high mortality due to unavailability of suitable diet especially at juveniles stage. This study focus on the healthy production with low cost by using sunflower meal to some extent replace fish meal. In this $3 \times 3$ factorial and completely randomized design study 324 fish were used. The acidification levels were $(0,1.5$ and $3 \%)$ whereas the phytase levels were $(0,500$ and 1000 FTU). The addition of $3 \%$ citric acid and 1000FTU phytase produced significant interaction effect on calcium and phosphorus digestibility and different body contents of $L$. rohita. Phytase and citric acid increased the digestibility of calcium and phosphorus with improvement in body dry matter, protein, fat, energy and ash contents of L. rohita. Acidification and phytase supplementation showed significant $(\mathrm{P}<0.05)$ interaction on body composition and mineral utilization in rohu. Citric acid and phytase supplementation improves the diet by increasing the availability of minerals and quality of fish by positively affecting the body composition of fish. $3 \%$ citric acid and 1000FTU phytase proves to be interacted positively. Further study is required to find the optimum levels of phytase and citric acid in this regard.
\end{abstract}

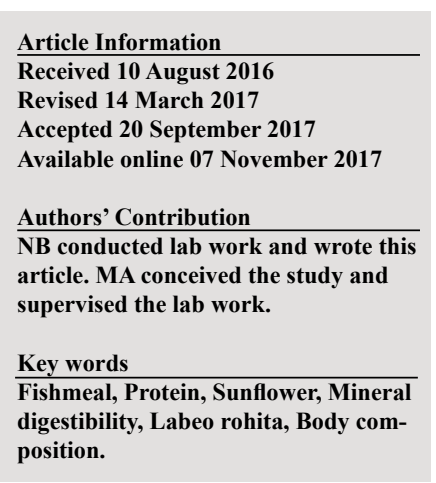

\section{INTRODUCTION}

$\mathrm{F}$ eed production for aquaculture is expected to be increased from 45 to 50,65 and 87 million metric ton from 2015, 2020 and 2025, respectively. Major cultureable species includes carps, catfish, tilapia, shrimp, salmon and other marine fish (Tacon and Metian, 2015). Many aquaculturist are focusing towards reduction in fish meal inclusion in diet with enzyme application as done in poultry. So they try to increase the phosphorus availability with other nutrients and minerals by using phytase (Vandenberg et al., 2011; Suprayudi et al., 2012). It can be said that the continuous change in fish feed formulation may include the increasing levels of plants ingredients with additives (enzymes and organic acids) for better nutritional quality of diet (Bedford and Partridge, 2010). Application of phytase relies on the specific activity in the gastric tract of animals and in fish species it vary according to the presence or absence of stomach (Lemos and Tacon, 2015; Rust, 2002). The reported $\mathrm{pH}$ for phytase activity remain between 4.0-6.0 (Greiner and Konietzny, 2010)

\footnotetext{
Corresponding author: bnaheed61@yahoo.com 0030-9923/2017/0006-2093 \$ 9.00/0

Copyright 2017 Zoological Society of Pakistan
}

which is a limitation in its use in agastric species like carp and shrimps (Dall et al., 1990; Kumar et al., 2012).

The effect of acidification is considerably studied in different animals. The citric acid supplementation can improve the $\mathrm{P}$ availability and minerals in fish (Sugiura and Hardy, 2000). Citric acid supplementation decreases the use of inorganic minerals in diet so plant meal based citric acid supplemented diet lower not only the phosphorus supplementation but also the phosphorus excretion (Hernandez et al., 2013). Other research results showed that acidification of diets can increase the availability of phosphorus from plants ingredients, making thereplacement of fish meal possible and decreasing the phosphate supplementation (Khajepour and Hosseini, 2012).

Phytase and citric acid improved not only growth but bone mineralization and immune response with improvement in intestinal working (Emami et al., 2013). Phytase (500 FTU/kg) with citric acid (3\%) have been reported to increase sodium, potassium, calcium, iron and manganese in bone (Baruah et al., 2005; Afzal et al., 2016) as well as weight gain, protein efficiency ratio and whole body ash (Baruah et al., 2007a) in Labeo rohita juveniles. The interactive mechanism of citric acid and phytase released minerals (calcium and phosphorus) in fish from phytate- calcium or phosphorus complex so that phytic 
acid become exposed to phytase for hydrolysis. Citric acid was given importance in the land-dwelling animal's studies (Liu et al., 2014). It is well known that citric acid can enhance the uptake of phosphorus, zinc and calcium in salmonids (Sugiura et al., 1998). Nevertheless, there is limited work on the effect of phytase and citric acid on fish. Therefore, in the present study, we used phytase with citric acid to explore the interactions between low fish meal diet, phytase and citric acid on Labeo rohita.

\section{MATERIALS AND METHODS}

Experimental design and diet

A $3 \times 3$ factorial experiment was designed with three citric acid levels $(0,1.5$ and $3 \%)$ and three phytase levels $(0,500$ and $1000 \mathrm{FTU} / \mathrm{kg})$ to study their main and interaction effects on calcium and phosphorus digestibility and body composition of fish. The ingredients and diets chemical composition is shown in Tables I and II.

All the ingredients of diet with different levels of citric acid were mixed in a mixer, moisture was added by adding distilled water and pellets were made using extruder. Phytase was supplemented by spraying method (Jackson et al., 1996) after pellet formation of diet. The pellets were then dried at room temperature and refrigerated at $4^{\circ} \mathrm{C}$ until the start of feeding trial. This experiment was a completely randomized design with triplicates of each treatment.

Table I.- Formulation of the experimental diets.

\begin{tabular}{lccccccccc}
\hline Ingredients & $\mathbf{C}_{\mathbf{0}} \mathbf{P}_{\mathbf{0}}$ & $\mathbf{C}_{\mathbf{0}} \mathbf{P}_{\mathbf{5 0 0}}$ & $\mathbf{C}_{\mathbf{0}} \mathbf{P}_{\mathbf{1 0 0 0}}$ & $\mathbf{C}_{\mathbf{1 . 5}} \mathbf{P}_{\mathbf{0}}$ & $\mathbf{C}_{\mathbf{1 . 5}} \mathbf{P}_{\mathbf{5 0 0}}$ & $\mathbf{C}_{\mathbf{1 . 5}} \mathbf{P}_{\mathbf{1 0 0 0}}$ & $\mathbf{C}_{\mathbf{3}} \mathbf{P}_{\mathbf{0}}$ & $\mathbf{C}_{\mathbf{3}} \mathbf{P}_{\mathbf{5 0 0}}$ & $\mathbf{C}_{\mathbf{3}} \mathbf{P}_{\mathbf{1 0 0 0}}$ \\
\hline Sunflower meal $^{\mathrm{a}}$ & 15 & 15 & 15 & 15 & 15 & 15 & 15 & 15 & 15 \\
Fish meal $^{\mathrm{a}}$ & 52 & 52 & 52 & 52 & 52 & 52 & 52 & 52 & 52 \\
Wheat flour $^{\mathrm{a}}$ & 10 & 10 & 10 & 10 & 10 & 10 & 10 & 10 & 10 \\
Rice polish $^{\mathrm{a}}$ & 16 & 16 & 16 & 16 & 16 & 16 & 16 & 16 & 16 \\
fish oil $_{\text {Vitamin premix }}^{\mathrm{b}}$ & 3 & 3 & 3 & 3 & 3 & 3 & 3 & 3 & 3 \\
Mineral premix $^{\mathrm{b}}$ & 1 & 1 & 1 & 1 & 1 & 1 & 1 & 1 & 1 \\
Ascorbic acid & 1 & 1 & 1 & 1 & 1 & 1 & 1 & 1 & 1 \\
Chromic oxide & 1 & 1 & 1 & 1 & 1 & 1 & 1 & 1 & 1 \\
Citric acid & 1 & 1 & 1 & 1 & 1 & 1 & 1 & 1 & 1 \\
\hline
\end{tabular}

${ }^{a}$ fish meal (\% dry matter): crude protein 23.4 , crude lipid 0.9 , ash 13.6 ; sunflower meal (\% dry matter): crude protein 6 , crude lipid2.2, ash1.05; wheat flour (\% dry matter): crude protein 1.2 , crude lipid 0.25 , ash 0.17 ; rice polish (\%dry matter): crude protein 1.76 , crude lipid 2.1 , ash $1.6 .{ }^{b}$ vitamin premix: same as Hussain et al. (2015b).

Table II.- Proximate and mineral composition of the experimental diets.

\begin{tabular}{lccccccccc}
\hline Diets & $\mathbf{C}_{\mathbf{0}} \mathbf{P}_{\mathbf{0}}$ & $\mathbf{C}_{\mathbf{0}} \mathbf{P}_{\mathbf{5 0 0}}$ & $\mathbf{C}_{\mathbf{0}} \mathbf{P}_{\mathbf{1 0 0 0}}$ & $\mathbf{C}_{\mathbf{1 . 5}} \mathbf{P}_{\mathbf{0}}$ & $\mathbf{C}_{\mathbf{1 . 5}} \mathbf{P}_{\mathbf{5 0 0}}$ & $\mathbf{C}_{\mathbf{1 . 5}} \mathbf{P}_{\mathbf{1 0 0 0}}$ & $\mathbf{C}_{\mathbf{3}} \mathbf{P}_{\mathbf{0}}$ & $\mathbf{C}_{\mathbf{3}} \mathbf{P}_{\mathbf{5 0 0}}$ & $\mathbf{C}_{\mathbf{3}} \mathbf{P}_{\mathbf{1 0 0 0}}$ \\
\hline Dry matter (\%) & 94.04 & 94.78 & 95.16 & 94.25 & 95.27 & 95.64 & 94.53 & 95.44 & 95.84 \\
Crude protein (\%) & 32.12 & 32.22 & 32.43 & 32.22 & 32.45 & 32.46 & 32.24 & 32.36 & 32.38 \\
Crude fat (\%) & 10.11 & 11.08 & 11.57 & 10.92 & 11.05 & 11.81 & 10.92 & 11.78 & 12.04 \\
Gross energy (kcal/g) & 2.64 & 2.66 & 2.64 & 2.67 & 2.62 & 2.64 & 2.63 & 2.69 & 2.63 \\
$\mathrm{P}(\%)$ & 2.60 & 2.64 & 2.65 & 2.63 & 2.92 & 3.06 & 3.15 & 3.27 & 3.48 \\
$\mathrm{Ca}(\%)$ & 3.27 & 3.54 & 3.8 & 3.68 & 3.82 & 3.91 & 3.81 & 3.89 & 4.21 \\
$\mathrm{Mg}(\%)$ & 0.82 & 0.85 & 0.92 & 0.85 & 0.92 & 0.99 & 0.92 & 1.03 & 1.07 \\
$\mathrm{~K}(\%)$ & 0.60 & 0.62 & 0.60 & 0.61 & 0.84 & 0.86 & 0.98 & 1.00 & 0.98 \\
$\mathrm{Na}(\%)$ & 0.62 & 0.64 & 0.63 & 0.64 & 0.93 & 0.95 & 0.99 & 0.99 & 0.98 \\
$\mathrm{Mn}(\%)$ & 0.0035 & 0.0038 & 0.0042 & 0.0043 & 0.0045 & 0.0048 & 0.0044 & 0.0051 & 0.0054 \\
$\mathrm{Zn}(\%)$ & 0.0094 & 0.0098 & 0.0114 & 0.0118 & 0.0122 & 0.0129 & 0.0124 & 0.0132 & 0.0148 \\
$\mathrm{Cu}(\%)$ & 0.0011 & 0.0012 & 0.0014 & 0.0013 & 0.0015 & 0.0016 & 0.0013 & 0.0015 & 0.0016 \\
$\mathrm{Fe}(\%)$ & 0.024 & 0.030 & 0.032 & 0.025 & 0.031 & 0.035 & 0.025 & 0.034 & 0.036 \\
\hline
\end{tabular}




\section{Fish and feeding trial}

To start this experiment, 400 Labeo rohita fish were taken from the fish seed hatchery Faisalabad (Punjab, Pakistan) and supplied to fish nutrition laboratory, Department of Zoology, Wild Life and Fisheries, University of Agriculture, Faisalabad, Pakistan. Formerly all fish were acclimatized to laboratory conditions for fifteen days and fed with the basal experimental diet (Table I). All fish were starved for $24 \mathrm{~h}$ before the start of feeding trial. Entire 324 fish with same magnitude $(3.4 \mathrm{~g})$ were disseminated in 27 steel tanks ( $70 \mathrm{~L})$ with 12 fish in each tank. Triplicate tanks (v shape at base) were used for each treatment attached as flow through system. Water temperature $26.5 \pm 0.3^{\circ} \mathrm{C}$, dissolved oxygen $6.7 \pm 0.05 \mathrm{mg} / \mathrm{L}$, $\mathrm{pH} 7.4 \pm 0.04$ and electric conductivity remain $1.32-1.53 \mathrm{dS} / \mathrm{m}$. throughout the experiment, fish were fed the experimental diet by hand till apparent satiation at 08:00 am for two months. Uneaten feed was collected after an hour of feeding.

\section{Sample collection and analysis}

Initial fish weight noted in the start of the research experiment. After the completion of feeding trial, the fish were weighed to determine the growth parameters, and chemical composition of diets and body was determined by following method: Dry matter was determined by constant heating at $105^{\circ} \mathrm{C}$ for $6 \mathrm{~h}$ and crude protein was determined by Kjeldahl method (AOAC, 1998). Gross energy was determined by oxygen bomb calorimeter and Crude fat was determined by petroleum ether extraction for $12 \mathrm{~h}$ in a Soxhlet (AOAC, 1998). Minerals were determined after digesting them in a nitric acid and perchloric acid mixture (2:1) according to AOAC (1998) and using Atomic Absorption Spectrophotometer (Hitachi Polarized Atomic Absorption Spectrometer, Z-8200) as recommended by manufacturers.

\section{Calculation and statistical analysis}

Apparent digestibility coefficients of calcium and phosphorus were calculated by using following equation:

Apparent digestibility of nutrients $(\%)=100-100 \times$ [percent chromic oxide in diet $\times$ percent nutrient in feces/ percent chromic oxide in feces $\times$ percent nutrient in diet]

Mean values of three replicate are reported \pm standard error of mean. After confirming the homogeneity of variance and normality, data was subjected to two way ANOVA using citric acid and phytase levels and differences were considered significant at $\mathrm{P}<0.05$. Data was also analysed using one way ANOVA followed by Tukey test using Costate (6.303, PMB320, Monterey, CA, 93940 USA).

Table III.- Calcium and phosphorus apparent digestibility coefficient.

\begin{tabular}{lccccccccc}
\hline Diets & $\mathbf{C}_{\mathbf{0}} \mathbf{P}_{\mathbf{0}}$ & $\mathbf{C}_{\mathbf{0}} \mathbf{P}_{500}$ & $\mathbf{C}_{\mathbf{0}} \mathbf{P}_{1000}$ & $\mathbf{C}_{1.5} \mathbf{P}_{\mathbf{0}}$ & $\mathbf{C}_{1.5} \mathbf{P}_{500}$ & $\mathbf{C}_{1.5} \mathbf{P}_{1000}$ & $\mathbf{C}_{\mathbf{3}} \mathbf{P}_{\mathbf{0}}$ & $\mathbf{C}_{\mathbf{3}} \mathbf{P}_{500}$ & $\mathbf{C}_{\mathbf{3}} \mathbf{P}_{1000}$ \\
\hline Calcium (\%) & $53.38 \pm$ & $58.95 \pm$ & $63.37 \pm$ & $60.03 \pm$ & $64.38 \pm$ & $63.83 \pm$ & $62.24 \pm$ & $64.63 \pm$ & $70.14 \pm$ \\
& $0.443^{\mathrm{e}}$ & $0.159^{\mathrm{d}}$ & $1.016^{\mathrm{bc}}$ & $0.267^{\mathrm{d}}$ & $0.147^{\mathrm{bc}}$ & $0.361^{\mathrm{bc}}$ & $0.124^{\mathrm{c}}$ & $0.103^{\mathrm{b}}$ & $0.467^{\mathrm{a}}$ \\
& & & & & & & & & \\
Phosphorus (\%) & $53.20 \pm$ & $56.54 \pm$ & $58.92 \pm$ & $58.20 \pm$ & $66.76 \pm$ & $67.95 \pm$ & $70.19 \pm$ & $73.35 \pm$ & $78.62 \pm$ \\
& $0.22^{\mathrm{f}}$ & $0.09^{\mathrm{e}}$ & $1.12^{\mathrm{e}}$ & $0.34^{\mathrm{e}}$ & $0.22^{\mathrm{d}}$ & $0.35^{\mathrm{cd}}$ & $0.43^{\mathrm{c}}$ & $0.45^{\mathrm{b}}$ & $0.25^{\mathrm{a}}$ \\
\hline
\end{tabular}

Table IV.- Body composition of $L$. rohita fed with graded levels of citric acid and phytase supplemented diet.

\begin{tabular}{|c|c|c|c|c|c|c|c|c|c|c|c|c|}
\hline Diets & $\mathbf{C}_{0} \mathbf{P}_{0}$ & $\mathbf{C}_{0} \mathbf{P}_{500}$ & $\mathbf{C}_{0} \mathbf{P}_{1000}$ & $\mathrm{C}_{1.5} \mathbf{P}_{0}$ & $\mathrm{C}_{1.5} \mathrm{P}_{500}$ & $\mathrm{C}_{1.5} \mathrm{P}_{1000}$ & $\mathbf{C}_{3} \mathbf{P}_{0}$ & $\mathrm{C}_{3} \mathbf{P}_{500}$ & $\mathrm{C}_{3} \mathbf{P}_{1000}$ & C.A & PHY & C.A $\times \mathbf{P H Y}$ \\
\hline Dry matter & $\begin{array}{l}21.16 \pm \\
0.008 h\end{array}$ & $\begin{array}{c}22.04 \pm \\
0.011 \mathrm{f}\end{array}$ & $\begin{array}{l}22.26 \pm \\
0.006 \mathrm{e}\end{array}$ & $\begin{array}{c}21.22 \pm \\
0.008 \mathrm{gh}\end{array}$ & $\begin{array}{l}22.34 \pm \\
0.011 \mathrm{~d}\end{array}$ & $\begin{array}{l}24.92 \pm \\
0.017 b\end{array}$ & $\begin{array}{l}21.28 \pm \\
0.014 \mathrm{~g}\end{array}$ & $\begin{array}{l}22.71 \pm \\
0.014 \mathrm{c}\end{array}$ & $\begin{array}{l}25.93 \pm \\
0.011 \mathrm{a}\end{array}$ & $<0.05$ & $<0.05$ & $<0.05$ \\
\hline $\begin{array}{l}\text { Crude } \\
\text { protein }\end{array}$ & $\begin{array}{c}16.84 \pm \\
0.015 i\end{array}$ & $\begin{array}{l}17.25 \pm \\
0.017 \mathrm{~g}\end{array}$ & $\begin{array}{l}17.66 \pm \\
0.025 f\end{array}$ & $\begin{array}{l}16.94 \pm \\
0.025 \mathrm{~h}\end{array}$ & $\begin{array}{c}18.14 \pm \\
0.02 \mathrm{c}\end{array}$ & $\begin{array}{l}19.25 \pm \\
0.011 b\end{array}$ & $\begin{array}{l}17.82 \pm \\
0.008 \mathrm{e}\end{array}$ & $\begin{array}{l}17.94 \pm \\
0.025 \mathrm{~d}\end{array}$ & $\begin{array}{l}19.55 \pm \\
0.017 \mathrm{a}\end{array}$ & $<0.05$ & $<0.05$ & $<0.05$ \\
\hline Crude fat & $\begin{array}{c}3.12 \pm \\
0.005 \mathrm{e}\end{array}$ & $\begin{array}{l}3.446 \pm \\
0.014 \mathrm{c}\end{array}$ & $\begin{array}{c}3.25 \pm \\
0.023 \mathrm{~d}\end{array}$ & $\begin{array}{c}2.873 \pm \\
0.008 f\end{array}$ & $\begin{array}{c}2.836 \pm \\
0.012 f\end{array}$ & $\begin{array}{l}3.846 \pm \\
0.012 b\end{array}$ & $\begin{array}{l}2.366 \pm \\
0.008 \mathrm{~g}\end{array}$ & $\begin{array}{c}3.236 \pm \\
0.02 \mathrm{~d}\end{array}$ & $\begin{array}{l}4.283 \pm \\
0.003 a\end{array}$ & $<0.05$ & $<0.05$ & $<0.05$ \\
\hline $\begin{array}{l}\text { Gross energy } \\
(\mathrm{Kcal} / \mathrm{g})\end{array}$ & $\begin{array}{l}1.56 \pm \\
0.43^{\mathrm{h}}\end{array}$ & $\begin{array}{l}1.60 \pm \\
1.63^{\mathrm{f}}\end{array}$ & $\begin{array}{l}1.64 \pm \\
2.02^{\mathrm{d}}\end{array}$ & $\begin{array}{l}1.58 \pm \\
1.35^{\mathrm{g}}\end{array}$ & $\begin{array}{l}1.62 \pm \\
1.83^{\mathrm{e}}\end{array}$ & $\begin{array}{l}1.68 \pm \\
1.87^{\mathrm{b}}\end{array}$ & $\begin{array}{l}1.58 \pm \\
2.28^{\mathrm{g}}\end{array}$ & $\begin{array}{l}1.66 \pm \\
2.28^{\mathrm{c}}\end{array}$ & $\begin{array}{c}1.79 \pm \\
1.95^{\mathrm{a}}\end{array}$ & $<0.05$ & $<0.05$ & $<0.05$ \\
\hline Crude ash & $\begin{array}{l}1.453 \pm \\
0.003 \mathrm{e}\end{array}$ & $\begin{array}{c}1.63 \pm \\
0.011 \mathrm{c}\end{array}$ & $\begin{array}{l}1.563 \pm \\
0.008 \mathrm{~d}\end{array}$ & $\begin{array}{l}1.436 \pm \\
0.012 \mathrm{e}\end{array}$ & $\begin{array}{l}1.426 \pm \\
0.008 \mathrm{e}\end{array}$ & $\begin{array}{l}1.886 \pm \\
0.003 b\end{array}$ & $\begin{array}{l}1.163 \pm \\
0.008 f\end{array}$ & $\begin{array}{l}1.613 \pm \\
0.008 \mathrm{c}\end{array}$ & $\begin{array}{l}2.133 \pm \\
0.003 \mathrm{a}\end{array}$ & $<0.05$ & $<0.05$ & $<0.05$ \\
\hline
\end{tabular}




\section{RESULTS}

Apparent digestibility coefficient of calcium and phosphorus

The maximum calcium digestibility was $70.14 \pm 0.467 \%$ of $\mathrm{C}_{3} \mathrm{P}_{1000}$ while minimum was $53.38 \pm 0.443$ $\%$ of $\mathrm{C}_{0} \mathrm{P}_{0}$. The analysis of variance of digestibility of calcium was shown in Table III. The digestibility of calcium of test diets remain significantly different from each other (Table III). The citric acid and phytase significantly affected the digestibility of calcium. The results also conform the synergistic effect of citric acid and phytase on calcium digestibility.

The maximum phosphorus digestibility was $78.62 \pm 0.25 \%$ of $\mathrm{C}_{3} \mathrm{P}_{1000}$ while minimum was $53.20 \pm 0.22$ $\%$ of $\mathrm{C}_{0} \mathrm{P}_{0}$. The phosphorus digestibility was also significantly affected by citric acid and phytase as in the case of calcium. The analysis of variance of digestibility of phosphorus was shown in Table III. The phosphorus digestibility of all test diets were significantly different from each other (Table III).

\section{Body composition}

The proximate compositions of the whole body of L. rohita was shown in Table IV. The results present significant difference among dietary treatments (Table IV). Citric acid and phytase affected the body composition of fish and there was also interaction effect of both on all the parameters studied (ash, protein, fat, energy and dry matter).

\section{DISCUSSION}

In the present study citric acid and phytase significantly affected the digestibility of nutrients in $L$. rohita diets. Acidification of diet with $3 \%$ citric acid significantly improved the apparent digestibility of phosphorus in L. rohita diets. Comparable improvements were observed in Beluga (Husso huso) at 3\% citric acid (Khajepour and Hosseini, 2010, 2012), L. rohita (Baruah et al., 2005), Oncorhynchus mykiss at 5\% and $1 \%$ citric acid, respectively (Sugiura et al., 2001; Hernandez et al., 2012), tiger shrimp at 2\% acidifications ( $\mathrm{Ng}$ et al., 2015), white shrimp at $4 \%$ acidification (Romano et al., 2015) in pigs at $1 \%$ of citric acid (Boling et al., 2000). Acidification may decrease the discharge of phosphorus in feces which improve the environment of aquatic organisms (Hernandez et al., 2012; Sarker et al., 2007). Minerals and nutrient's digestibility and absorption depend upon the acidifier levels (Partanen and Mroz, 1999; Hedayati et al., 2013).

The higher apparent digestibility of phosphorus was observed at $1000 \mathrm{FTU} / \mathrm{kg}$ in the present study. Similarly significant $(\mathrm{P}<0.05)$ results of phytase were observed by Baruah et al. (2007b) and Roy et al. (2014) in L. rohita, Schafer et al. (1995) in C. carpio, Papatryphon and Soares (2001) in striped bass, Yoo et al. (2005) in Korean rockfish. Storebakken et al. (1998) in Atlantic salmon observed increase in apparent digestibility coefficient (20 to $30 \%$ ) of phosphorus with the increase of plant meal by the addition of phytase. Phytate phosphorus remain unavailable to fish owing to the absence of enzyme in stomach of fish (NRC, 1983) as Phytate is the principal anti-nutritional factor in diets based on crops which binds minerals (Satoh et al., 1989). Enzymatic breakdown of phytate by phytase may increase the retention and availability of phosphorus (Cao et al., 2007; Morales et al., 2014) and may decrease the discharge of phosphorus in feces (Yan and Reigh, 2002; Zhu et al., 2014) by increasing utilization of phosphorus (Liu et al., 2012; Jackson et al., 1996; Sugiura et al., 2001).

There was a positive interaction of citric acid and phytase in the present study and higher phosphorus digestibility was observed at 3\% citric acid and $1000 \mathrm{FTU} /$ $\mathrm{kg}$. Sugiura et al. (2001) reported significant increment in the apparent absorption of phosphorus by the citric acid $(5 \%)$ and phytase supplementation in the diet of rainbow trout, Oncorhynchus mykiss and similar effect of citric acid and phytase on phosphorus was observed in birds (Hariharan and Gangadevi, 2015). Citric acid remain important not only in terrestrial animal studies (Liu et al., 2014) but also in aquatic animals like fish for enhancing the uptake of calcium, phosphorus and zinc (Sugiura et al., 1998). Higher apparent digestibility coefficient of calcium was observed in the present work. Acidification of diet has been reported in animal feed to chelate calcium and phosphorus and increases their solubility, availability and utilization in rainbow trout (Vielma et al., 1999).

Phytase can improve the digestibility coefficient of calcium in fish but feed ingredients also influences the activity of phytase (Bedford, 2000). Phytase (20,000 FTU/ $\mathrm{kg}$ ) improved the availability of minerals in pigs (Zeng et al., 2015). Apparent digestibility coefficient of calcium and phosphorus was improved by $4000 \mathrm{FTU} / \mathrm{kg}$ of phytase in Oncorhynchus mykiss (Morales et al., 2015). So the supplementation of phytase in feed may increase the bioavailability of minerals (Vielma et al., 2004; Debnath et al., 2005a).

The dry matter content of L. rohita was increased in the present study and higher dry matter content was observed in fish fed on diet acidified by $3 \%$ citric acid. Khaled (2015) and Cuvin-Aralar et al. (2011) observed no negative effect of acidification on body composition of Nile tilapia (Oreochromis niloticus). No effect of citric acid (3\%) for moisture in muscles was observed in common carp (Cyprinus carpio) by Khajepour et al. 
(2012) and in Beluga (Huso huso) by Khajepour et al. (2011). In the present study there was increase in body dry matter of $L$. rohita with the increasing level of phytase and higher dry matter content in body was observed at $1000 \mathrm{FTU} / \mathrm{kg}$ phytase. Similar results were observed by Sardar et al. (2007) in common carp (Cyprinus carpio) but Hassan et al. (2013) observed no effect of phytase on the dry matter content. These differences in results may be due to difference in experimental conditions, composition of diets, source of phytase and species of fish.

There was significant interaction of phytase and citric acid in the present study with partial replacement of fish meal with sunflower meal in Labeo rohita diet. Citric acid $3 \%$ and phytase $1000 \mathrm{FTU} / \mathrm{kg}$ was considered best in the present study with positive effect on protein contents of fish. Similar results were obtained by Shah et al. (2016) in Labeo rohita. But Nezhad et al. (2008) stated that citric acid may not affect the ability of phytase in chicks. It was suggested that this might be due to the none influencing behavior of citric acid on phytase activity to low P diets, or citric acid (organic acid) might had speedily metabolized in the body and negligibly effected the $\mathrm{pH}$ of intestine.

The results of the present study showed that acidification have significant effect on crude lipid contents of body composition of $L$. rohita. 3\% citric acid in diet of fish positively affected the crude fat contents of fish whereas $1.5 \%$ citric acid decreased the body lipid contents in partially replaced diets. An increasing trend in body lipid was observed at $1.5 \%$ acidified diet in Nile Tilapia (Oreochromis niloticus) (Hassaan et al., 2014). Khaled (2015) and Cuvin-Aralar et al. (2011) observed negative effect of acidification on body composition of Nile tilapia with non- significant crude lipid contents. Similar results were observed in poultry (Park et al., 2009) and aquaculture (Ng et al., 2011).

There was an increasing trend of lipid contents in body of $L$. rohita with the increasing supplementation level of phytase in partially replaced diets. Phytase 1000 FTU/kg significantly influenced the crude lipid contents of fish body in the present research work.

Similar results were obtained in $O$. niloticus by Hassan et al. (2013), in common carp (Cyprinus carpio) by Kumar et al. (2011), Atlantic salmon (Salmo salar) by Sajjadi and Carter (2004a), P. pangasius by Debnath et al. (2005a, 2007) and in pigs by Shelton et al. (2003) and Brady et al. (2003). The complex of phytate with lipid and other nutrients lower down its availability (Debnath et al., 2005a) as observed by Usmani and Jafri (2002). In the present study, results showed that phytase 1000 FTU/ $\mathrm{kg}$ made available the fat and other nutrients from phytic acid to fish which increases their level in body. Baruah et al. (2007a, b, c) also reported same findings in L. rohita.
Khajepour and Hosseini (2010) observed that 2 and $3 \%$ of citric acid can increase ash content in muscles of beluga. Other studies by Sugiura et al. (2001) on rainbow trout, Baruah et al. (2007a), on Labeo rohita and Hossain et al. (2007) on red sea bream supported these results. Acidification of diet by citric acid can significantly increase iron in whole body of fish (Vielma et al. 1999). Acidification of diet chelates minerals in rainbow trout and increases their solubility and mineral utilization is improved (Vielma et al. 1999). Two factors affecting the results are; 1) acidification and solubilization and 2) chelation of cations. Citric acid crosses the brush border in intestine by mechanism of $\mathrm{Na}$ transport system (Wolffram, 1990, 1992).

Dietary phytase supplementation increased ash contents (Zhu et al., 2014), alike supportive results were observed in rainbow trout (Sugiura et al., 2001), $P$. pangasius (Debnath et al., 2005b), L. rohita (Baruah et al., 2007b), pig (Jendza et al., 2005; Veum et al., 2006), and poultry (Deepa et al., 2011). The increment in ash in body by phytase reveals that phytase had released minerals during hydrolysis of phytate. Phytase can hydrolyze phytic acid which increases minerals contents and result into increment in the body ash content (Masumoto et al., 2001; Liebert and Portz, 2005; Debnath et al., 2005a).

\section{Statement of conflict of interest}

Authors have declared no conflict of interest.

\section{REFERENCES}

AOAC, 1998. Official methods of analysis. Association of official analytical chemists, Washington, DC, USA.

Afzal, M., A. Amanat, S.Z.H. Shah and S.M. Hussain., 2016. Effect of acidification in a phytase sprayed sunflower meal based diet on growth and dietary nutrient digestibility performances of Labeo rohita Juveniles. Pak. J. Zool., 48: 1165-1169.

Baruah, K., Pal, A.K., Sahu, N.P., Debnath, D., Norouztallab, P. and Sorgeloos, P., 2007a. Microbial phytase supplementation in rohu, Labeo rohita diet enhances growth performance and nutrient digestibility. J. World Aquacult. Soc., 38: 129-137. https://doi.org/10.1111/j.1749-7345.2006.00081.x

Baruah, K., Pal, A.K., Sahu, N.P., Debnath, D., Yengkokpam, S. and Mukherjee, S.C., 2007b. Interactions of microbial phytase, citric acid and crude protein level on mineral utilization by rohu, Labeo rohita Juveniles. J. World Aquacult. Soc., 38: 238-249. https://doi.org/10.1111/j.17497345.2007.00092.x 
Baruah, K., Pal, A.K., Sahu, N.P., Jain, K.K., Mukherjee, S.C. and Debnath, D., 2005. Dietary protein level, microbial phytase, citric acid and their interactions on bone mineralization of Labeo rohita (Hamilton) juveniles. Aquacult. Res., 36: 803-812. https://doi. org/10.1111/j.1365-2109.2005.01290.x

Baruah, K., Sahu, N.P., Pal, A.K., Jain, K.K., Debnath, D. and Mukherjee, S.C., 2007c. Dietary microbial phytase and citric acid synergistically enhances nutrient digestibility and growth performance of Labeo rohita (Hamilton) juveniles at suboptimal protein level. Aquacult. Res., 38: 109-120.

Bedford, M. and Partridge, G., 2010. Enzymes in farm animal nutrition, 2nd edn. CABI, Oxford Shire, pp. 319. https://doi.org/10.1079/9781845936747.0000

Bedford, M.R., 2000. Exogenous enzymes in monogastric nutrition - their current value and future benefits. Anim. Feed Sci. Technol, 86: 1-13. https://doi.org/10.1016/S0377-8401(00)00155-3

Boling, S.D., Webel, D.M., Mavromichalis, I., Parsons, C.M. and Baker, D.H., 2000. The effects of citric acid on phytate-phosphorus utilization in young chicks and pigs. J. Anim. Sci., 78: 682-689. https:// doi.org/10.2527/2000.783682x

Brady, S.M., Callan, J.J., Cowan, D., McGrane, M. and O'Doherty, J.V., 2003. Effect of two microbial phytases on the performance and nutrient retention on grower-finisher pigs fed barley-maizesoyabean meal-based diets. Iran. J. Agric. Fd. Res., 42: 101-117.

Cao, L., Wang, W.M., Yang, C.T., Yang, Y., Diana, J., Yakupitiyage, A., Luo, Z. and Li, D.P., 2007. Application of microbial phytase in fish feed. Enzyme Microbiol. Technol., 40: 497-507. https:// doi.org/10.1016/j.enzmictec.2007.01.007

Cuvin-Aralar, M.L.A., Lückstädt, C., Schroeder, K. and Kühlmann, K.J., 2011. Effect of dietary organic acid salts, potassium diformate and sodium diformate on the growth performance of male Nile tilapia Oreochromis niloticus. Bull. Fish Biol., 13: 33-40.

Dall, W., Hill, B.J., Rothlisberg, P.C. and Staples, D.J., 1990. The biology of Penaeidae. Adv. Mar. Biol., 27: 1-489.

Debnath, D., Pal, A.K., Sahu, N.P., Jain, K.K., Yengkokpam, S. and Mukherjee, S.C., 2005 b. Mineral status of Pangasius pangasius (Hamilton) fingerlings in relation to supplemental phytase: absorption, whole body and bone mineral content. Aquacult. Res., 36: 326-335. https://doi. org/10.1111/j.1365-2109.2004.01204.x

Debnath, D., Pal, A.K., Sahu, N.P., Jain, K.K. and Yengkokpam, S., 2005a. Effect of dietary microbial phytase supplementation on growth and nutrient utilization of Pangasius pangasius (Hamilton) fingerlings. Aquacult. Res., 36: 180-187. https:// doi.org/10.1111/j.1365-2109.2004.01203.x

Debnath, D., Pal, A.K., Sahu, N.P., Yengkokpam, S., Baruah, K., Choudhury, D. and Venkateshwarlu, G., 2007. Digestive enzymes and metabolic profile of $L$. rohita fingerlings fed diets with different crude protein levels. Comp. Biochem. Physiol. Part B., 146: 107-114. https://doi.org/10.1016/j. cbpb.2006.09.008

Deepa, C., Jeyanthi, G.P. and Chandrasekaran, D., 2011. Effect of phytase and citric acid supplementation on the growth performance, phosphorus, calcium and nitrogen retention on broiler chicks fed with low level of available phosphorus. Asian J. Poult. Sci., 5: 28-34. https://doi.org/10.3923/ajpsaj.2011.28.34

Emami, N.K., Naeini, S.Z. and Ruiz-Feria, C.A., 2013. Growth performance, digestibility, immune response and intestinal morphology of male broilers fed phosphorus deficient diets supplemented with microbial phytase and organic acids. Livest. Sci., 157: 506-513. https://doi.org/10.1016/j. livsci.2013.08.014

Greiner, R. and Konietzny, U., 2010. Phytases: biochemistry, enzymology and characteristics relevant to animal feed use. In: Enzymes in farm animal nutrition (eds. M. Bedford and G. Partridge), 2nd edn. CABI, Oxford Shire, UK, pp. 96-128. https://doi.org/10.1079/9781845936747.0096

Hariharan, T. and Gangadevi, P., 2015. Efficacy of citric acid and microbial phytase on the tibial characteristics, tibial and serum mineral concentrations in broiler chicken. Ind. J. Anim. Res., 49: 328-332. https://doi.org/10.5958/09760555.2015.00085.0

Hassaan, M.S., Wafa, M.A., Soltan, M.A., Goda, A.S. and Mogheth, N.M.A., 2014. Effect of dietary organic salts on growth, nutrient digestibility, mineral absorption and some biochemical indices of Nile tilapia; Oreochromis niloticus L. fingerlings. J. World appl. Sci., 29: 47-55.

Hassan, M.S., Solyan, M.A., Agouz, H.M. and Badr, A.M., 2013. Influences of calcium/phosphorus ratio on supplemental microbial phytase efficiency for Nile tilapia (Oreochromis niloticus). Egypt. J. aquat. Res., 39: 205 -213.

Hedayati, M., Manafi, M., Yari, M. and Vafaei, P., 2013. Effects of supplementing diets with an acidifier on performance parameters and visceral organ weights of broilers. Eur. J. zool. Res., 2: 49-55.

Hernández, A.J., Satoh, S. and Kiron, V., 2012. 
Supplementation of citric acid and amino acid chelated trace elements in low-fish meal diet for rainbow trout affect growth and phosphorus utilization. J. World aquacul. Soc., 43: 688-696. https://doi.org/10.1111/j.1749-7345.2012.00589.x

Hernandez, A.J., Satoh, S. and Kiron, V., 2013. The effect of citric acid supplementation on growth performance, phosphorus absorption and retention in rainbow trout (Oncorhynchus mykiss) fed a low-fishmeal diet. Cien. Invest. Agra., 40: $397-406$. https://doi.org/10.4067/S071816202013000200014

Hossain, M.A., Pandey, A. and Satoh, S., 2007. Effects of organic acids on growth and phosphorus in red sea bream Pagrus major. Fish. Sci., 73: 1309-1317.

Jackson, L.S., Li, M.H. and Robinson, E.H., 1996. Use of microbial phytase in channel catfish Ictalurus punctatus diets to improve utilization of phytate phosphorus. J. World aquacul. Soc., 27: 309-313.

Jendza, J.A., Dilger, R.N., Adedokun, S.A., Sands, J.S. and Adeola, O., 2005. Escherichia coli phytase improves growth performance of starter, grower, and finisher pigs fed phosphorus-deficient diets. J. Anim. Sci., 83: 1882-1889. https://doi. org $/ 10.2527 / 2005.8381882 x$

Khajepour, F. and Hosseini, S.A., 2010. Mineral status of juvenile Beluga (Huso huso) fed citric acid supplemented diets. World appl. Sci., 11: 682-686.

Khajepour, F. and Hosseini, S.A., 2012. Calcium and phosphorus status in juvenile Beluga (Huso huso) fed citric acid-supplemented diets. Aquacult. Res., 43: 407-411. https://doi.org/10.1111/j.13652109.2011.02843.x

Khajepour, F., Hosseini, S.A. and Imanpour, M.R., 2011. Study on some hematological and biochemical parameters of juvenile Beluga (Huso huso) fed citric acid supplemented diet. Global Vet. Chem., 115: 238-242.

Khaled, M., 2015. Effect of organic acid salt supplementation on growth performance and feed utilization in practical diets of hybrid tilapia $((q O)$. niloticus $x$ ô O. aureus) fingerlings. Egypt. J. Anim. Prod., 52: 81-88.

Kumar, V., Sinha, A.K., Makkar, H.P.S., Boeck, G.D. and Becker, K., 2012. Phytate and phytase in fish nutrition. J. Anim. Physiol. Anim. Nutr., 96: 335-364. https://doi.org/10.1111/j.14390396.2011.01169.x

Kumar, V., Makkar, H.P.S. and Becker, K., 2011. Detoxified Jatropha curcas kernel meal as a dietary protein source, growth performance, nutrient utilization and digestive enzymes in common carp (Cyprinus carpio L.) fingerlings. Aquacult. Nutr., 17: 313-326. https://doi.org/10.1111/j.13652095.2010.00777.x

Lemos, D. and Tacon, A.G.J., 2015. Use of phytases in fish and shrimp feeds: A review. Rev. Aquacult., 0: $1-17$.

Liebert, F. and Portz, L., 2005. Nutrient utilization of Nile tilapia Oreochromis niloticus fed plant based low phosphorus diets supplemented with graded levels of different sources of microbial phytase. Aquaculture, 248: 111-119. https://doi. org/10.1016/j.aquaculture.2005.04.009

Liu, L., Zhou, Y., Wu, J., Zhang, W., Abbas, K., Fang, L.X. and Luo, Y., 2014. Supplemental graded level of neutral phytase using pretreatment and spraying methods in the diet of grass carp, Ctenopharyngodon idellus. Aquacult. Res., 45: 1932-1941. https://doi. org/10.1111/are.12145

Liu, L.W., Su, J. and Luo, Y., 2012. Effect of partial replacement of dietary monocalcium phosphate with neutral phytase on growth performance and phosphorus digestibility in gibel carp, Carassius auratus gibelio (Bloch). Aquacult. Res., 43: 1404-1413. https://doi.org/10.1111/j.13652109.2011.02944.x

Masumoto, T., Tamure, B. and Shimeno, S., 2001. Effects of phytase on bioavailability of phosphorus in soybean meal based diets for Japanese flounder Paralichthys olivaceus. Fish. Sci., 67: 1075-1080. https://doi.org/10.1046/j.1444-2906.2001.00363.x

Morales, G.A., Marquez, L., Rodriganez, M.S.D., Bermudez, L., Robles, R. and Moyano, F.J., 2014. Effect of phytase supplementation of a plant-based diet on phosphorus and nitrogen bioavailability in sea bream Sparus aurata. Aquacult. Nutr., 20: 172182. https://doi.org/10.1111/anu.12063

Morales, G.A., Denstadli, V., Collins, S.A., Mydland, L.T., Moyano, F.J, and Overland, M., 2015. Phytase and sodium diformate supplementation in a plantbased diet improves protein and mineral utilization in rainbow trout (Oncorhynchus mykiss). Aquacult. Nutr., 22: 1301-1311. https://doi.org/10.1111/ anu. 12340

Nezhad, Y.E., Sis, N.M., Gholshani, A.A., Saedi, Y. and Aminvakili, R., 2008. The effects of combination of citric acid and microbial phytase on the concentration of some minerals of serum and parameters of mineralization of tibia in commercial laying hens. Asian J. Anim. Vet. Adv., 3: 375-380. https://doi.org/10.3923/ajava.2008.375.380

Ng, K., Cheng-Fang, L., Chandana, P.S., Pui-Kwan, A.H. and Ping-Yi, Y., 2011. Reduced membrane 
fouling in a novel bio-entrapped membrane reactor for treatment of food and Beverage processing wastewater. Water Res., 45: 4269-4278. https://doi. org/10.1016/j.watres.2011.05.031

Ng, W., Koh, C., Teoh, C. and Romano, N., 2015. Farm- raised tiger shrimp, Penaeus monodon, fed commercial feeds with added organic acids showed enhanced nutrient utilization, immune response and resistance to Vibrio harveyi challenge. Aquaculture, 449: 69-77. https://doi.org/10.1016/j. aquaculture.2015.02.006

NRC, 1983. Nutrient requirements of coldwater fishes and shellfishes. National Academy Press, Washington, DC, pp. 63 pp.

Papatryphon, E. and Soares, Jr. J.H., 2001. The effect of phytase on apparent digestibility of four practical plant feed stuffs fed to striped bass, Morone saxatilis. Aquacult. Nutr., 7: 161-167. https://doi. org/10.1046/j.1365-2095.2001.00174.x

Park, K.W., Rhee, A.R., Um, J.S. and Paik, I.K., 2009. Effect of dietary available phosphorus and organic acids on the performance and egg quality of laying hens. Appl. Poult. Res., 18: 598-604. https://doi. org/10.3382/japr.2009-00043

Partanen, K.H. and Mroz, Z., 1999. Organic acids for performance enhancement in pig diets. Nutr. Res. Rev., 12: 117-145. https://doi. org/10.1079/095442299108728884

Romano, N., Koh, C. and Ng, W., 2015. Dietary microencapsulated organic acid blend enhances growth, phosphorus utilization, immune response, hepatopancreatic integrity and resistance against Vibrio harveyi in white shrimp, Litopenaeus vannamei. Aquaculture, 435: 228-236. https://doi. org/10.1016/j.aquaculture.2014.09.037

Roy, T., Banerjee, G., Dan, S.K., Ghosh, P. and Ray, A.K., 2014. Improvement of nutritive value of sesame oilseed meal in formulated diets for rohu, Labeo rohita (Hamilton), fingerlings after fermentation with two phytase-producing bacterial strains isolated from fish gut. Aquacult. Int., 22: 633-652. https://doi.org/10.1007/s10499-0139691-0

Rust, M., 2002. Nutritional physiology. In: Fish nutrition (eds. J.E. Halver and R.W. Hardy). Academic Press, San Diego, pp. 367-452.

Sajjadi, M. and Carter, C.G., 2004a. Effect of phytic acid and phytase on feed intake, growth, digestibility and trypsin activity in Atlantic salmon (Salmo salar L.). Aquacult. Nutr., 10: 135-142. https://doi. org/10.1111/j.1365-2095.2003.00290.x

Sardar, P., Randhawa, H.S., Abid, M. and Prabhakar,
S.K., 2007. Effect of dietary microbial phytase supplementation on growth performance, nutrient utilization, body compositions and haematobiochemical profiles of Cyprinus carpio (L.) fingerlings fed soy protein-based diet. Aquacult. Nutr., 13: 444-456. https://doi.org/10.1111/j.13652095.2007.00497.x

Sarker, M.S.A., Satoh, S. and Kiron, V., 2007. Inclusion of citric acid and/or amino acid chelated trace elements in alternate plant protein source diets affects growth and excretion of nitrogen and phosphorus in red sea bream Pagrus major. Aquaculture, 262: 436-443. https://doi.org/10.1016/j.aquaculture.2006.10.007

Satoh, S., Poe, W.E. and Wilson, R.P., 1989. Effect of supplemental phytate and/or tricalcium phosphate on weight gain, feed efficiency and zinc content in vertebrae of channel catfish. Aquaculture, 80: 155161. https://doi.org/10.1016/0044-8486(89)902810

Schafer, A., Koppe, W.M., Meyer-Burgdorff, K.H. and Gunther, K.D., 1995. Effects of a microbial phytase on the utilization of native phosphorus by carp in a diet based on soybean meal. Water Sci. Technolol., 31: 149-155.

Shah, S.Z.H., Afzal, M., Akmal, A., Fatima, M. and Hussain, S.M., 2016. Effect of citric acid and phytase on growth performance and mineralization of Labeo rohita juveniles fed soybean meal based diet. Int. J. Agric. Biol., 18: 111-116. https://doi. org/10.17957/IJAB/15.0071

Shelton, J.L., Southern, L.L., Bidner, T.D., Persica, M.A., Braun, J., Cousins, B. and McKnight, F., 2003. Effect of microbial phytase on energy availability and lipid and protein deposition in growing swine. J. Anim. Sci., 81: 2053-2062. https://doi.org/10.2527/2003.8182053x

Storebakken, T., Shearer, K.D. and Roem, A.J., 1998. Availability of protein, phosphorus and other elements in fish meal, soy-protein concentrate and phytase-treated soy-protein-concentrate-based diets to Atlantic salmon, Salmo salar. Aquaculture, 161: 365-379. https://doi.org/10.1016/S00448486(97)00284-6

Sugiura, S.H. and Hardy, R.W., 2000. Environmentally friendly feeds. In: Encyclopedia of aquaculture (ed. R.R. Stickney). Wiley-Interscience, New York, pp. 299-310.

Sugiura, S.H., Dong, F.M. and Hardy, R.W., 1998. Effects of dietary supplements on the availability of minerals in fish meal; preliminary observations. Aquaculture, 160: 283-303. https://doi.org/10.1016/ S0044-8486(97)00302-5 
Sugiura, S.H., Gabaudan, J., Dong, F.M. and Hardy, R.W., 2001. Dietary microbial phytase supplementation and the utilization of phosphorus, trace minerals and protein by rainbow trout Oncorhynchus mykiss (Walbaum) fed soybean meal-based diets. Aquacult. Res., 32: 583-592. https://doi.org/10.1046/j.13652109.2001.00581.x

Suprayudi, M.A., Harianto, D. and Jusadi, D., 2012. The effect of phytase levels in the diet on the digestibility and growth performance of white shrimp Litopenaeus vannamei. J. Aquacult. Ind., 11: 103-108.

Tacon, A.G.J. and Metian, M., 2015. Feed matters: satisfying the feed demand of aquaculture. Rev. Fish. Sci. Aquacult., 23: 1-10. https://doi.org/10.10 80/23308249.2014.987209

Usmani, N. and Jafri, A.K., 2002. Influence of dietary phytic acid on the growth, conversion efficiency, and carcass composition of mrigal, Cirrhinus mrigala fry. J. World aquacul. Soc., 33: 199-204.

Vandenberg, G.W., Scott, S.L., Sarker, P.K., Dallaire, V. and Noue, J., 2011. Encapsulation of microbial phytase: effects on phosphorus bioavailability in rainbow trout (Oncorhynchus mykiss). Anim. Feed Sci. Technol., 169: 230-243. https://doi. org/10.1016/j.anifeedsci.2011.07.001

Veum, T.L., Bollinger, D.W., Buff, C.E. and Bedford, M.R., 2006. A genetically engineered Escherichia coli phytase improves nutrient utilization, growth performance, and bone strength of young swine fed diets deficient in available phosphorus. J. Anim. Sci., 84: 1147-1158. https://doi. org $/ 10.2527 / 2006.8451147 x$

Vielma, J., Ruohonen, K. and Lall, S.P., 1999. Supplemental citric acid and particle size of fish bone-meal influence the availability of minerals in rainbow trout Oncorhynchus mykiss (Walbaum). Aquacult. Nutr., 5: 65-71. https://doi.org/10.1046/ j.1365-2095.1999.00092.x

Vielma, J., Ruohonen, K., Gabaudan, J. and Vogel, K., 2004. Top spraying soybean meal based diets with phytase improves protein and mineral digestibility but not lysine utilization in rainbow trout, Oncorhynchus mykiss (Walbaum). Aquacult. Res., 35: 955-964. https://doi.org/10.1111/j.13652109.2004.01106.x

Wolffram, S., Bisang, B., Grenacher, B. and Scharrer, E., 1990. Transport of tri- and dicarboxylic acids across the intestinal brush border membrane of calves. Nutrition, 120: 767-774.

Wolffram, S., Hagemann, C., Grenacher, B. and Scharrer, E., 1992. Characterization of the transport of triand di carboxylates by pig intestinal brush border membrane vesicles. Comp. Biochem. Physiol., 101A: 759-767. https://doi.org/10.1016/03009629(92)90355-T

Yan, W. and Reigh, R.C., 2002. Effects of fungal phytase on utilization of dietary protein and minerals, and dephosphorylation of phytic acid in the alimentary tract of channel catfish Ictalurus punctatus fed an all-plant-protein diet. J. World aquacul. Soc., 33: 10-22. https://doi.org/10.1111/j.1749-7345.2002. tb00473.X

Yoo, G.Y., Wang, X., Choi, S., Han, K., Kang, J.C. and Bai, S.C., 2005. Dietary microbial phytase increased the phosphorus digestibility in juvenile Korean rockfish, Sebastes schlegeli fed diets containing soybean meal. Aquaculture, 243: 315-322. https:// doi.org/10.1016/j.aquaculture.2004.10.025

Zeng, Z., Li, Q., Tian, Q., Zhao, P., Xu, X., Yu, S. and Piao, X., 2015. Super high dosing with a novel Buttiauxella phytase continuously improves growth performance, nutrient digestibility and mineral status of weaned pigs. Biol. Trace Elem. Res., 168: 103-109. https://doi. org/10.1007/s12011-015-0319-2

Zhu, Y., Qiu, X., Ding, Q., Duan, M. and Wang, C., 2014. Combined effects of dietary phytase and organic acid on growth and phosphorus utilization of juvenile yellow catfish Pelteobagrus fulvidraco. Aquaculture, 430: 1-8. https://doi.org/10.1016/j. aquaculture.2014.03.023 